\title{
The proportion of immature breeders as a reliable early warning signal of population decline: evidence from the Spanish imperial eagle in Donana
}

\author{
Miguel Ferrer ${ }^{\mathrm{a}, *}$, Vincenzo Penteriani ${ }^{\mathrm{a}}$, Javier Balbontın ${ }^{\mathrm{a}}$, Massimo Pandolfi ${ }^{\mathrm{b}}$ \\ ${ }^{a}$ Department of Applied Biology, Estación Biológica de Doñana, Consejo Superior de Investigaciones Científicas, Avda.de María Luisa s/n, \\ Pabellón del Perú, Seville 41013, Spain \\ bZoological Laboratory, Urbino University, Via M.Oddi, 21, Urbino 61029, Italy
}

Received 24 September 2002; received in revised form 7 February 2003; accepted 13 February 2003

\begin{abstract}
Methods to evaluate population trends have recently received particular attention because of perceived declines in several species during the 20th century. We investigated whether age at first breeding could be used as an "early warning signal" to detect possible changes in population trends in long-lived species with deferred maturity using data from the Spanish imperial eagle (Aquila adalberti) population in Donana National Park (Spain). This bird of prey is an endangered species that has suffered a rapid decline in this population during the last 10 years. As a result of our 27-year monitoring (1976-2002) study, we detected that an increase in immature breeding birds occurred before population decline became evident. The proportion of immature-plumaged breeders in the population was significantly higher during the period of decline than during the period of stability. In our case, more than $10 \%$ of immature breeders can be considered as an "early warning signal" that anticipates population decline. Owing to the ignorance of this warning signal, urgent actions for the recovery of this eagle population started 10 years later than necessary, and when population size had been reduced.
\end{abstract}

Keywords: Age at first breeding; Population monitoring and trends; Population decline; Early warning signals; Spanish imperial eagle

\section{Introduction}

Conservation of birds is of great concern for researchers, conservationists and the public at large, as a result of the general reduction in abundance and distribution of many birds species during the 20th century. Consequently, there are many monitoring programs designed to detect bird population trends of endangered or threatened species or populations (Tucker and Heath, 1994). The monitoring of animal abundance and distribution over long time series has been used as a method to determine population trends. However, census techniques detect changes in population only after

\footnotetext{
* Corresponding author. Tel.: +34-95-4232340; fax: +34-955621125.

E-mail address: mferrer@ebd.csic.es (M. Ferrer).
}

they have occurred, and therefore lack predictive capability.

Recently, Balbontin et al. (2003) proposed that regular monitoring of the age-structure of territorial pairs of long-lived bird species may have predictive power using demographic traits and, consequently, could be used as an early warning signal of changes in population viability. Because an increase of non-adult plumage birds within the breeding portion of populations of species with deferred maturity could be a consequence of temporal reductions in adult survival rates that lead to a future decrease in population size, we can anticipate a population decline before population size starts to decrease.

The main aim of this paper was to further test our previous hypothesis that the age at first breeding can be used as a reliable early warning signal to predict changes in bird population trends. 


\section{Methods}

We analysed data from the Spanish imperial eagle (Aquila adalberti) population of Donana National Park, southwestern Spain $\left(37^{\circ} \mathrm{N}, 6^{0} 30^{\circ} \mathrm{W}\right)$ collected during 1976-2002. Three main habitats can be distinguished in the area: (1) Mediterranean scrubland, formed by Halimium spp., Cistus libanotis, Erica spp. with scattered cork oaks (Quercus suber), small stone pine (Pinus pinea) woods, and Eucalyptus spp. plantations; (2) marsh, mainly covered by Scirpus spp., flooded in winter and dry in summer; and (3) coastal sand dunes, with vegetation mainly made up of Ammophila arenaria, Corema album, and Juniperus phoenicia. The climate is of Mediterranean type with Atlantic influence.

The Spanish imperial eagle is the most endangered bird of prey in Europe and one of the rarest raptors in the world (Collar and Andrew, 1988), with a total population estimated at little more than 140 pairs (Ferrer, 2001). It is a large (2500-3500 g), sedentary and territorial bird of prey, with a low reproductive rate $(0.75$ chicks per pair per year), an immaturity period of $4-5$ years and an estimated longevity of 21-22 years maximum (Ferrer and Calderon, 1990). It can therefore be included among the "survival species", which are characterised by having a late mature reproduction age, a low fecundity rate and a high adult survival rate (Sæther et al., 1996).

The Spanish imperial eagle can be divided into three easily distinguishable plumage classes: (1) juvenile, with a tawny-coloured plumage that remains until the bird is 3 years old; (2) subadult, with dark patches over a tawny base, present in 4-5 year-old birds; and (3) adult, predominantly dark brown with characteristic white markings appearing from the age of 5 years (Ferrer and Calderon, 1990). These differences facilitate the detection of a mixed-age pair (one member of the pair in non-adult plumage).

The entire National Park area was surveyed at the beginning of each breeding season (January-February, during the courtship and nest site selection period; Ferrer, 2001) to determine if pairs were present on territories. The sedentary behaviour of this species and its tendency to call repeatedly greatly facilitate observation of a pair on territory. Therefore, all breeding attempts were detected as well as those pairs that did not breed. In summary, we know population size and age classes of breeding individuals for 26 years. The eagle population at Donana is apparently disjunct from other breeding populations: the nearest nesting eagles are $300 \mathrm{~km}$ away (Ferrer, 2001).

The data set was analysed by linear regression and one-way analysis of variance (ANOVA) to evaluate the possible relationships between percent of immature breeding birds and population saturation levels, mortality and number of pairs, as well as variations in the frequencies of immature as breeders. When data were not normally distributed, they where $\log _{\mathrm{e}}$, square-root or arcsine square-root transformed prior for parametric tests (Sokal and Rohlf, 1998). Means are given with T 1 S.D. All tests were two-tailed and statistical significance was set at $\mathrm{P}<0.05$. All tests were computed using the STATISTICA 6.0 software package.

\section{Results}

The eagle population of Donana National Park remained stable during the period 1976-1992 (Fig. 1), with 15-16 pairs breeding at high density (occupying 20,000 ha of available habitat inside the National Park with a mean territory size of $1200 \mathrm{ha}$ ). After 1992, this population suffered a notable decline dropping to only seven pairs in 2002.

More than 360 breeding attempts were monitored during the 27-year study and 46 of these were mixed pairs $(12.7 \%)$ involving 66 immature breeding birds. The frequency of breeders in immature plumage varied over the years with a mean value of 1.7 mixed pairs and 2.4 immature eagles breeding per year. The presence of at least one immature in a breeding pair was the highest in 2001, when mixed pairs represented $42.8 \%$ of the total breeding pairs and $30 \%$ of the breeding individuals in immature plumage. The percentage of immature breeders was significantly different between 1976-1991 and $1992-2002$ periods (1976-1991, $\overline{\mathrm{x}}=3.29 \% \mathrm{~T} 3.41 \%$; 1992-2002, $\quad \overline{\mathrm{x}}=21.01 \%, \quad \mathrm{~T} 7.05 \% ; \quad \mathrm{F}_{1,25}=75.979$ ， $\mathrm{P}<0.001$; Table 1).

Starting from 1993, the population size decreased by about $6 \%$ per year (Fig. 1) with a significant increase in percent of immature breeders $(r=-0.654, \mathrm{P}<0.001$, $\mathrm{n}=27$ ). In addition, a significant relationship between adult eagles found dead in Donana and percent of immature breeders was found $(r=0.540, \quad P=0.006$, $\mathrm{n}=27$ ); that is, a higher proportion of immature breeders were detected in those years characterised by a higher mortality of adult eagles.

\section{Discussion}

Unlike in the other subpopulations of the Spanish imperial eagle (Ferrer, 2001), the comparison of the

Table 1

Percentage of immature breeders in the Donana population of Spanish imperial eagle according to population trend

\begin{tabular}{llrccr}
\hline \multirow{2}{*}{ Period } & Population trend & \multicolumn{4}{c}{$\%$ Immature breeders } \\
\cline { 3 - 6 } & & Mean & S.D. & $99 \%$ CI & Range \\
\hline $1976-1991$ & Stable & 3.29 & 3.41 & $0.7-5.8$ & $0-10$ \\
$1992-1902$ & Declining & 21.01 & 7.05 & $14.3-27.7$ & $10-30$ \\
\hline
\end{tabular}




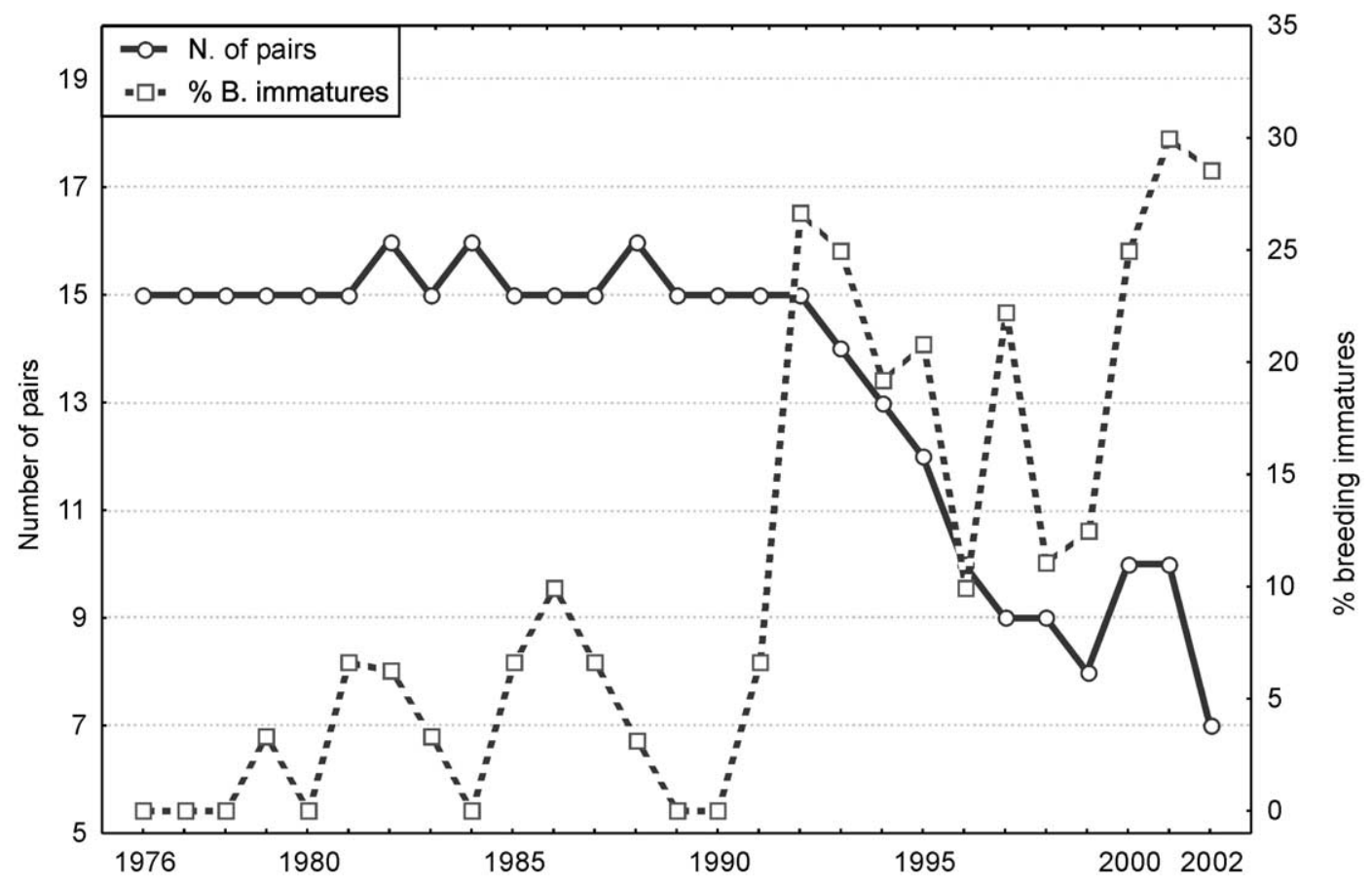

Fig. 1. Decline of Spanish imperial eagle population in Donana (SW Spain) and increase in percent of immature birds in breeding pairs.

1976-2002 censuses showed that the number of breeding pairs has declined markedly in Donana National Park. Coincidentally with this decline, we have detected changes in age of mates: during recent years, the percentage of breeding immature eagles increased. Since 1976 to 1991, only 3.3\% of the breeding eagles were in non-adult plumage, whereas during the last 11 years, $21 \%$ of the breeders were immature birds. Percentage of immature breeders suddenly increased (from $6.7 \%$ in 1991 to $26.7 \%$ in 1992) one year before population size started to decrease, and during the whole period of population decline showed significantly higher values than during the period of population stability (Fig. 1).

Age at first breeding is an important factor in the population dynamics of avian species (Lack, 1968; Henny et. al., 1970; Newton, 1979). Birds in immature plumage are capable of breeding, but do not normally do so because any gaps in the territorial system are usually filled by older birds. However, when the death rate is increased, more territories become vacant, enabling younger birds to breed (Newton, 1979). Balbontın et al. (2003), proposed two possible causes of an increase in immature breeders. First, it could be due to an increase in mortality rate, either immature or adult (Valverde, 1960; Newton, 1979; Novelletto and Petretti, 1980; Ratcliffe, 1980; Steenhof et al., 1983) or it could be due to an increase in the availability of resources such as nest sites or food supply, such as occurs when populations are increasing (McGowan, 1975; Newton, 1976; Wyllie and Newton, 1991; Brommer et al., 1998). Evidence from our study supported the hypothesis that a decrease in age at first breeding was due to an increase in adult mortality rate, as shown by the relationship between the numbers of adult eagles found dead and the proportion of immature breeders. The alternative hypothesis, that an increase in resource availability led to an increase in immature breeders and thus increased the population size, was not supported by our observations. The overall decline observed in the Donana population (nearly $-6 \%$ per year, Fig. 1 ) can only be explained by an increase in adult mortality. As previous analyses have shown (Ferrer and Calderon, 1990), adult mortality rate alone can strongly affect the size of the population over a short period. The intensity of this effect could be very high in the Donana population due to its relative geographical isolation from other breeding populations of Spanish imperial eagles, the nearest nesting eagles being $300 \mathrm{~km}$ away (Ferrer, 2001). In other situations (e.g. closer subpopulations), we might expect a slower decline in population size owing to greater immigration, as well as an increase of immature breeders.

Wild rabbits (Oryctolagus cuniculus) have suffered in Donana, as in many parts of their European range, with population reductions in the last 10 years due to viral haemorrhagic disease (Beltran, 1991; Villafuerte and Moreno, 1991; Villafuerte et al., 1994). This rabbit population decline has led hunters to poison predators. Consequently, the decrease of rabbits could be the ultimate cause of the increase observed in eagles poisoned during the last 10 years. Although illegal, the use of poison against generalist predators (typically foxes Vulpes vulpes) accounted for more than $50 \%$ of the total number of paired eagles found dead since 1991 (Ferrer, 
unpublished data). The fact that young eagles disperse over a distance of $90 \mathrm{~km}$ apart from the breeding area, and there are large differences in the intensity of hunting (Ferrer, 2001), could explain how they encounter poisoned baits. Furthermore, populations are less sensitive to an increase in immature mortality than to adult mortality because of the demographic characteristics of this species (Ferrer and Calderon, 1990). The increased frequency of immature eagles in breeding pairs in Donana appears to be linked to a decrease in adult survival rate. A decrease in adult survival has also been related to a decrease in the age of first breeding in the wandering albatross (Diomedea exulans, Weimerskirch and Jouventin, 1987), golden eagle (Aquila chrysaetos, Sandeman, 1957; Steenhof et al., 1983), and Bonelli's eagle (Hieraaetus fasciatus, Balbontın et al., 2003).

Conservation of endangered species, particularly in the case of small populations, needs more efficient methods than merely censusing the breeding population to be effective. Consequently, a system of "early warning signals" that detected possible future changes in population trends before they occurred, similar to "early diagnosis" in human health, would increase the chance of saving populations from extinction. In the Spanish imperial eagle, a percentage of immature breeders $>10 \%$ could be considered as a reliable "early warning signal" that anticipates a population decline (Table 1). Unfortunately, because we only censused breeding pairs we failed to recognise this warning signal until the size had dropped to seven pairs, 10 years after the first symptoms appeared (in 1992, 26.7\% of breeders were immature eagles but the population was still saturated with 15 breeding pairs). In 2002, an urgent action plan for the recovery of the eagle population was started in Donana.

Our results show the importance of long-term studies of demographic traits, especially age at first breeding, in long-lived territorial avian species, characterised by deferred maturity. Regularly checking the age of pairs can provide a powerful method to anticipate changes in population viability. The development of "early warning signals" that allow population declines to be predicted beforehand could be a very useful tool in conservation biology.

\section{Acknowledgements}

We are indebted to L. Garcia, R. Cadenas and M.L. Chacon for helping in the field. We are also grateful to J. Watson and to an anonymous referee for their useful comments on the early version of the manuscript. Support for this project was provided by FUNGESMA (Glaxo-wellcome) and CSIC.

\section{References}

Balbontın, J., Penteriani, V., Ferrer, M., 2003. Variation in the age of mates as an early warning signal of changes in population trends? The case of Bonelli's eagle in Andalusia. Biological Conservation $109,417-423$

Beltran, J.F., 1991. Temporal abundance pattern of the wild rabbit in Donana. SW Spain. Mammalia 55, 591-599.

Broomer, J.E., Pietiainen, H., Kolunen, H., 1998. The effect of age at first breeding on Ural owl lifetime reproductive success and fitness under cyclic food conditions. Journal of Animal Ecology 67, 359369.

Collar, N. J., Andrew, P., 1988. The ICBP World Checklist of Threatened Birds. ICBP Technical Publication 8.

Ferrer, M., 2001. The Spanish Imperial Eagle. Lynx editions, Barcelona.

Ferrer, M., Calderon, J., 1990. The Spanish imperial eagle Aquila adalberti in Donana National Park south west Spain: a study of population dynamics. Biological Conservation 51, 151-161.

Henny, C.J., Overton, W.S., Wight, H.M., 1970. Determining parameters for population using structure models. Journal of Wildlife Management 34, 690-703.

Lack, D., 1968. Ecological Adaptations for Breeding in Birds. Methuen and Co, London, UK.

McGowan, J.D., 1975. Distribution, Density and Productivity of Goshawk in Interior Alaska. Juneau. Alaska Department of Fish and Game, Alaska.

Newton, I., 1976. Breeding of Sparrowhawk Accipiter nisus in different environments. Journal of Animal Ecology 45, 831-849.

Newton, I., 1979. Population Ecology of Raptors. Buteo Books, Vermillion, SD.

Novelletto, S., Petretti, F., 1980. Ecologia dell'Aquila reale negli Appennini. Rivista italiana di Ornitologia 50, 249-262.

Ratcliffe, D., 1980. The Peregrine Falcon. Buteo Books, Vermillon, $\mathrm{SD}$.

Sæther, B.-E., Ringsby, T.H., Roskaft, E., 1996. Life history variation, population processes and priorities in species conservation: towards a reunion of research paradigms. Oikos 77, 217-226.

Sandeman, P.W., 1957. The breeding success of Golden Eagles in the southern Grampians. Scottish Naturalist 69, 148-152.

Sokal, R.R., Rohlf, F.J., 1998. Biometry, third ed. W.H. Freeman, New York, NY.

Steenhof, K., Kochert, M.N., Doremus, J.H., 1983. Nesting of subadult Golden Eagles in Southwestern Idaho. Auk 100, 743-747.

Tucker, G.M., Heath, M.F., 1994. Birds in Europe: Their Conservation Status. Birdlife International. Birdlife Conservation Series No. 3, Cambridge, UK.

Valverde, J.A., 1960. La population d'Aigles Imperiaux Aquila heliaca adalberti des marismas du Guadalquivir: son evolution depuis un siecle. Alauda 28, 20-26.

Villafuerte, R., Moreno, S., 1991. Rabbit haemorrhagic disease RHD in Donana National Park SW Spain. In: International Congress of Game Biology. Godollo, Hungary, pp. 107-108.

Villafuerte, R., Calvete, C., Cortazar, C., Moreno, S., 1994. First epizootic of rabbit haemorrhagic disease in free living population of Oryctolagus cuniculus at Donana National Park Spain. Journal of Wildlife Disease 30, 176-179.

Weimerskirch, H., Jouventin, P., 1987. Population dynamics of the wandering albatross, Diomedea exulans, of the Crozet Island: causes and consequences of the population decline. Oikos 49, 315-322.

Wyllie, I., Newton, I., 1991. Demography of an increasing population of sparrowhawks. Journal of Animal Ecology 60, 749-766. 